DOI 10.37882/2500-3682.2021.04.03

\title{
ОБСУЖДЕНИЕ НРАВСТВЕННЫХ ВОПРОСОВ СЕМЬИ И ОБЩЕСТВА В ИСКУССТВЕ И СРЕДСТВАХ МАССОВОЙ ИНФОРМАЦИИ
}

\section{DISCUSSION OF MORAL ISSUES OF FAMILY AND SOCIETY IN ART AND MASS MEDIA}

M. Borovik

Summary: The article examines the attitude to religion in modern society in the context of art and the media, provides examples of high-profile scandals on this topic. Methods of comparison and analysis of wellknown news articles and public comments prove the urgent need to strike a balance between freedom of speech and freedom of conscience. The subject of the research will be articles from the official mass media, comments of public figures. The novelty lies in the use of fresh news materials on the deviant behavior of recipients on contemporary art.

Keywords: morality, religion, art, mass media, self-control in the press.
$\mathrm{H}$ а протяжении многих столетий проблема нравственных вопросов семьи и общества остается актуальной. С постоянным техническим и научным прогрессом происходит переоценка ценностей, и порой радикальные, непринятые взгляды ученых и общественных деятелей находят отклик в сердцах людей спустя промежуток времени. Такими не признанными новаторами были Джордано Бруно и Галилео Галилей. Русский авангард XX века оказал огромное влияние на искусство всего мира. Характерными чертами этого направления можно назвать радикальный отказ от культурного наследия, принципиально новые приемы и формы в изобразительном искусстве. Однако существуют примеры современного творчества, которые откровенно переходят грань этических и нравственных вопросов, что вызывает не только недовольство общества, но и радикальные методы борьбы с творцами.

Эта тема с давних времен привлекает внимание многих исследователей, но вместе с тем ее актуальность возрастает в связи с новыми аспектами этой проблематики, проявляющихся в современной деятельности работников искусства и средств массовой информации.

Существенный вклад в изучении воздействия религии на другие сферы жизни общества внесли в своих работах Макс Вебер, Питер Бергер и Эмиль Дюркгейм. В рамках отечественной науки можно выделить научных

\author{
Боровик Мария Викторовна \\ Аспирант, Краснодарский государственный \\ институт культуры \\ borovik_maria@mail.ru
}

Аннотация: В статье рассматривается отношение к религии в современном обществе в контексте искусства и средств массовой информации, приводятся примеры громких скандалов на данную тематику. Методами сравнения и анализа известных новостных статей и публичных комментариев доказывается острая необходимость в установлении баланса между свободой слова и свободой совести. Предметом исследования станут статьи из официальных средств массовой информации, комментарии общественных деятелей. Новизна заключается в использовании свежих новостных материалов по девиантному поведению реципиентов на современное искусство.

Ключевые слова: мораль, религия, искусство, средства массовой информации, самоконтроль в прессе.

деятелей: Ольгу Минаеву и Юрия Борункова. В статье мы рассмотрим современное искусство с помощью социального, исторического и культурологического подходов. Среди основных задач можно выделить: анализ и сравнение реакций реципиентов современного искусства и СМИ, а также выявление граней дозволенного в творчестве.

Предметом исследования станут статьи из официальных средств массовой информации и комментарии общественных деятелей. Новизна заключается в использовании свежих новостных материалов по девиантному поведению реципиентов на современное искусство.

В демократическом обществе наряду со свободой слова неизбежен самоконтроль в искусстве, публичных высказываниях или средствах массовой информации. Иначе с появлением новых форм и выразительных средств придет нравственный упадок населения. Мораль как регуляция взаимоотношений индивидов внутри общества помогает сохранить целостность, структуру и стабильность населения. Без четкого баланса между свободой слова и свободой совести будут неизбежно появляться громкие скандалы и конфликты между творцами и реципиентами.

Нравственность - это социально-философская категория, обозначающая свод незакрепленных правил, 
традиций, норм и ценностей человеческого жития, регламентирующих поведение личности в социуме и задающих его образец и идеал. Русская православная церковь играет важную роль в обсуждении нравственных вопросов семьи и общества.

Громким скандалом на религиозную тематику можно назвать случай, произошедший в Краснодаре в 2012 году. Выставка современного искусства, привезенная известным скандальным галеристом Маратом Гельманом была сорвана протестующими. Дело в том, что некоторые картины, по мнению кубанского духовенства и казаков, задевали чувства верующих. Борьба с современным искусством закончилась плевком в лицо галеристу. Прорвавшись через заслон полицейских, настоятель храма в честь иконы Пресвятой Богородицы «Всех скорбящих Радость» протоиерей Алексий Касатиков плюнул в лицо Марату Гельману. За это на него было наложено церковное прещение. Так борьба за нравственность и идеалы перешла невидимую черту «дозволенного», вызвала непозволительную агрессию среди реципиентов и громкий скандал в обществе.

И тут можно вспомнить другой случай, происшедший в Америке в начале XX века. Излюбленного местной публикой писателя Максима Горького не заселили в отель с Марией Андреевой, так как они не состояли в браке. В тот период в Соединенных Штатах Америки религиозные и моральные позиции горячо обсуждались как в обществе, так и среди политиков. Поэтому тот случай, что они не были женаты - вызвало отторжение у многих жителей.

Несмотря на то, что прошло более ста лет, религия в США играет очень важную роль. Взять хотя бы инаугурацию в президенты - она начинается с утренней молитвы в церкви, расположенной через дорогу от Белого дома. После чего в Капитолии будущий правитель произносит слова присяги на Библии.

В России сложилась ситуация с религией иначе: в период советского союза популязировали коммунизм и атеизм. А после развала - церковь вновь стала обретать свою значимость. Поэтому в средствах массовой информации начали просачиваться материалы, связанные со скандальным поведением верующих.

Примером может послужить фильм «Матильда» Алексея Учителя. Ещё до выхода киноленты в прокат она стала предметом острого общественного конфликта. Причиной протестов был трейлер, который якобы исказил историческую правду и очернил память Николая II, канонизированного Русской православной церковью. После этого со стороны организации «Христианское го- сударство - Святая Русь» появились угрозы создателям фильма и поджоги кинотеатров. Только на Кубани в Министерство культуры было направлено более 100 писем от жителей с просьбой запрета показа фильма. Конфликт разгорелся еще больше после обращения депутата Государственной Думы Натальи Поклонской в Генпрокуратуру с просьбой проверить киноленту «Матильда» на предмет оскорбления чувств верующих. Она приложила немало усилий для запрета картины и аннулировании лицензии на прокат.

Однако позже в интервью на радио «Комсомольская правда» Наталья Поклонская призналась, что совершила ошибку в истории с фильмом «Матильда». Этот конфликт привлек большой интерес у зрителей, его посмотрело более 2 млн человек. Однако кассовые сборы киноленты оказались довольно скромными - около 9 миллионов долларов. Это почти в три раза меньше бюджета картины. К слову, этот фильм снимался за государственный счет.

Другой пример вмешательства со стороны духовенства в работу культурных деятелей можно назвать закрытие оперы «Тангейзер» (2015 год), которая была поставлена в Новосибирском театре оперы и балета. В постановке был использован образ Иисуса Христа и христианская символика в неканоническом формате. Против спектакля выступил новосибирский митрополит Тихон, который получил жалобы от православных зрителей, однако сам постановку не смотрел. Митрополит не только пожаловался на театр в Министерство культуры, но и потребовал возбудить дело об осквернении предметов религиозного почитания. Дело против директора театра было возбуждено - правда, его позже закрыли, не найдя в постановке признаков правонарушения. Судьба самого спектакля оказалась печальной: директор театра Борис Мездрич был уволен, а пришедший ему на смену Владимир Кехман первым же делом снял «Тангейзер» с репертуара. Спасти постановку не смог даже митинг, прошедший в Новосибирске.

В том же 2015 году появилась статья в газете «Московский Комсомолец» в Питере», в которой говорилось о намерениях РПЦ взять во владение Исаакиевский Собор и вернуть ему статус Храма. Два года музейное сообщество билось за Собор, который никогда не был в собственности церкви. Более двухсот тысяч человек подписали петицию на сайте change.org против передачи Исаакиевского Собора. Причиной этому послужили опасения, что усилий РПЦ будет недостаточно для проведения масштабных реставраций уникальных объектов культурного наследия, поддержания их в надлежащем состоянии. После передачи РПЦ за содержание и реставрационные работы придется платить из бюджета. Сейчас 
музей полностью на самоокупаемости. В итоге Исаакий удалось отстоять. Теперь в нем проходят и богослужения, и музейные экскурсии.

В 2019 году в газете «Московский Комсомолец» появилась новая публикация под названием «Исаакий №2». Русская православная церковь попросила контроль над Спасо-Андроньевским монастырем, в том числе и над расположенным на его территории музеем Рублева. В своих требованиях РПЦ исходила из закона 2010 года «O передаче религиозным организациям имущества религиозного назначения, находящегося в государственной собственности». Этот документ позволяет церкви иметь право на религиозные объекты, находящиеся в собственности государства. Однако руководство музея такую инициативу не поддержало, заявив, что если здание будет передано церкви - то музей можно будет выкинуть на улицу. На данный момент судебные тяжбы за монастырь продолжаются.

Конфликты на религиозную тематику происходят не только в православной вере, абсолютно во всех мировых конфессиях существуют громкие скандалы реципиентов после просмотра некоторых произведений искусства и публикаций в СМИ. Так, например, в январе 2015 года случилось шокирующее на весь мир преступление - террористический акт в редакции Charlie Hebdo в Париже. Этот журнал часто попадал в конфликты своими провокационными карикатурами на религиозную тематику, многие исламские радикалы угрожали редакции, бросали в окна коктейли Молотова. Никто не подозревал, что за борьбой за свободу слово произойдет череда убийств. В результате нападения вооружённых исламских боевиков 7 января 2015 года погибло двенадцать человек, ранено одиннадцать. Это оказалось только началом череды нападений. Всего жертвами январских терактов 2015 года стали семнадцать человек. В 2020-м список жертв увеличился.

В пригороде Парижа кухонным ножом был обезглавлен учитель истории. Убийство совершено на почве религиозного конфликта. На одном из уроков учитель Самуэль Пати решил обсудить с подростками карикатуры на пророка Мухаммеда, опубликованные в Charlie Hebdo. Чтобы не задеть чувства мусульман, он предложил им отвернуться или выйти. Тринадцатилетняя девочка осталась и решила доказать учителю, что рисунок обнаженного пророка - это кощунство. Однако ее никто не услышал, и конфликт разгорелся до печальных последствий. Отец девочки Брахим Шнина записал два видео и опубликовал их в интернете, где призвал предпринять меры против педагога. Ролик разлетелся по социальным сетям, где на него наткнулся с детства живший в Париже восемнадцатилетний чеченец Абдулак Анзо- ров. Он с Пати лично не был знаком, но готов был решить проблему радикально и по-своему.

За свободой слова общественные деятели должны понимать свою ответственность. Радикальные взгляды религиозных фанатиков зачастую к самой вере не имеют ничего общего. Однако провокационное искусство способно стать катализатором для противоправных действий. Поэтому важно стараться находить «золотую середину» между свободой совести и свободой слова. В решении этой проблемы необходимо соблюдать принципы взаимного уважения и отказа от провокационного поведения с обеих сторон. После скандальной акции Pussy Riot в Храме Христа Спасителя в 2013 году был подписан Федеральный закон № 136-Ф3 «О внесении изменений в статью 148 Уголовного кодекса Российской Федерации и отдельные законодательные акты РФ в целях противодействия оскорблению религиозных убеждений и чувств граждан». Согласно новой редакции статьи, публичные действия, совершенные в целях оскорбления религиозных чувств верующих - будут наказываться штрафом в размере до 300 тысяч рублей, либо принудительными работами на срок до одного года, либо лишением свободы на тот же срок. Панк-группа Pussy Riot продолжила свое творчество, несмотря на вышедший закон. В Сочи в 2014 году солисток этой группы казаки отхлестали нагайкой. Инцидент вызвал у жителей не только жалость к участницам панк-группы, но и поддержку казаков.

Последнее десятилетие ознаменовалось чередой громких скандалов, которые дали повод для дискуссий об отношении к религии в современном обществе. Например, убийство голландского режиссера Тео Ван Гога по религиозным мотивам в 2004 году. Он был автором документального фильма о жизни мусульманских женщин. Не менее известным стал и так называемый карикатурный скандал в Дании, который вызвал существенные политические разногласия внутри западных стран. Такие примеры лишь доказывают необходимость установления границ дозволенного в искусстве и средствах массовой информации на религиозную тематику, ведь именно сегодня эти резонансные случаи с обеих сторон порождают нетерпимость и непримиримость друг к другу.

«Свобода одного человека заканчивается там, где начинается свобода другого» - в своем высказывании Михаил Бакунин лишь напоминает, что не существует абсолютной безграничной свободы. Ее рамками будет служить закон и свобода других людей. Считаю, что данную проблематику необходимо изучать более тщательно и выявить конкретные черты «дозволенного» в обсуждении религиозных вопросов. 


\section{ЛИТЕРАТУРА}

1. Минаева О.Д. Русская журналистика в документах. История надзора / редакция Б.И. Есина, Я.Н. Засурского. М.: Аспект пресс, 2003.5 с.

2. Вебер М. Хозяйственная этика мировых религий: Опыты сравнительной социологии религии. Конфуцианство и даосизм: пер. с англ. / под ред. О.В. Кольдюшова. СПб.: Владимир Даль. 2017. 267 - 303 с.

3. Бергер П.Л. Священная завеса. Элементы социологической теории религии: пер. с англ. Р. Сафронова / под ред. С.И. Елагина. М.: Новое литературное обозрение. 2019. 346 с.

4. Дюркгейм Э. Элементарные формы религиозной жизни. Тотемическая система в Австралии: пер. с франц. А. Апполонова, Т. Котельниковой / под ред. А. Апполонова. М.: Издательский дом «Дело» РАНХиГС. 2018. 736 с.

5. Патриархия.ru В.Р. Легойда: Современное состояние СМИ вызывает у наших сограждан очень серьезные вопросы // Русская Православная Церковь. Официальный сайт Московского Патриархата. - 03.10.2011. URL: http://www.patriarchia.ru/db/text/1637378.html

6. Тихон (Шевкунов), епископ. «Матильда»: точка обратного отсчёта // Независимая газета. — 25.09.2017. URL: http://www.ng.ru/ faith/2017-09-25/1_7080_matilda.html

7. Яковлева Е. Епископ Тихон Шевкунов: Вымысел и обман // Российская газета. - 14.12.2016.

8. Сапронова Ю., Ким А., Алексенко Ф. Дело «Матильды»: как фильм Учителя стал самым скандальным в России. РБК. - 15.09.2017.

9. Опера «Тангейзер»: в чем суть скандала? «Тангейзер», Вагнер // FB.ru. URL: https://fb.ru/article/236546/opera-tangeyzer-v-chem-sut-skandala-tangeyzervagner

10. Кузнецова К. Тема передачи РПЦ Исаакия и Спаса на Крови напоминает покушение на убийство музея // МK.RU Санкт-Петербург - 12.08.2015.

11. Невинная И., Райкина М., Трегубов А. Исаакий №2 // Московский комсомолец №27927 - 16.03.2019.

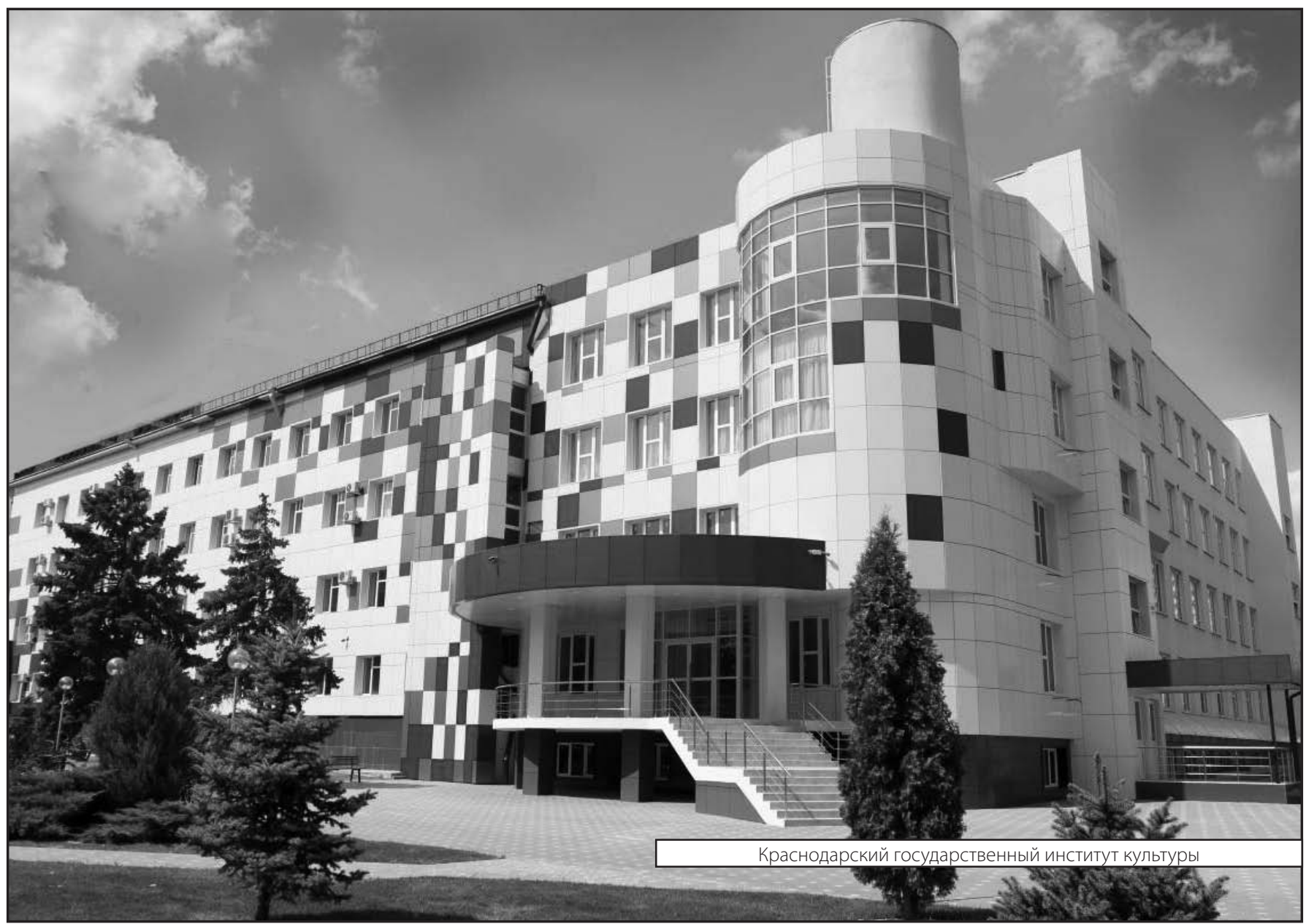

